\title{
The Effect of Health Education of Anemia in Relation with Knowledge of First-Trimester Pregnant Women in PMB Putu Mastiningsih, Abiansemal
}

\author{
Ni Gusti Ayu Pramita Aswitami ${ }^{1}$, Ni Putu Mirah Yunita Udayani ${ }^{1}$ \\ ${ }^{1}$ Midwifery Study Program, STIKES Bina Usada Bali \\ Email: tami_chant@yahoo.com
}

Received 1 February 2019; Accepted 1 February 2019; Published 22 May 2019

\begin{abstract}
Anemia in pregnancy is the condition in which the level of mother's hemoglobin is less than $12 \mathrm{gr} / \mathrm{dL}$. According to WHO's data, the maternal death in developing countries accounts for $40 \%$ related to anemia state in pregnancy. Most of the case is caused by iron deficiency and acute bleeding. Prevention of anemia can be done by giving the iron supplement tablets. However, by giving iron tablets alone, is not enough if pregnant women do not have any compliance about how to take it on. Maternal knowledge is known as the influence of that compliance. In order to increase their knowledge about anemia, providing the health education is a pivotal role. Health education in pregnancy care is an effort to influence other people, whether individuals, groups, or communities so that they do what is expected of education actors. In this study, the influenced object is pregnant women. The purpose is an increase of maternal knowledge about anemia in pregnant women and improving their compliance in consuming the iron tablets. This study aims to determine the effect of health education about anemia on knowledge of first-trimester pregnant women in Praktek Mandiri Bidan (PMB) Putu Mastiningsih, Abiansemal. The pre-experimental study was designed with one group pre-test and post-test. This study was involved 30 sample of pregnant women in Pregnant I in PMB Putu Mastiningsih, Abiansemal from May-July 2018. The data on pregnant women's knowledge pre and post-test about anemia were collected and then satistically analyzed. The results of the study concluded that there was a positive effect of health education on anemia on the knowledge of first trimester-pregnant women about anemia in Putu Mastiningsih PMB with a p-value $<0.005$. It is recommended for health workers to improve the provision of health education as an effort to improve the knowledge of pregnant women about anemia.
\end{abstract}

Keywords: Anemia, pregnant women, health education

Copyright $(0) 2019$ STIKes Surya Mitra Husada

All right reserved.

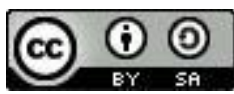

This is an open-acces article distributed under the terms of the Creative Commons AttributionShareAlike 4.0 International License.

\section{INTRODUCTION}

According to the Survey Demografi Kesehatan Indonesia (SDKI) in 2012, Maternal Mortality Rate (MMR) in Indonesia amounted to 359 per 100,000 live births, Maternal Mortality Rate (MMR) again showed a decrease to 305 per 100,000 live births (Kemenkes RI,, 2015). Whereas MMR in Bali Province in 2014 amounted to 70 per 100,000 live births far lower than the 2015 Millennium Development Goals target of 102 per 100,000 live births and also far lower than the national target in 2010 which was 110 per 100,000 live births (Dinas Kesehatan Provinsi Bali, 2015). Through the 
MMR data in Bali it shows that maternal and child health programs are on target and must be improved. Efforts to improve maternal and child health can be provided through health care care in pregnancy until the puerperium. Pregnancy is the presence of a fetus in the womb of a woman which is preceded by the process of fertilization. If the mother has experienced signs of pregnancy, the mother must immediately get a pregnancy check up at the health service regularly. This is intended for early detection of pregnant women, usually in pregnant women vulnerable to anemia in pregnancy. Anemia is a condition where there is a lack of hemoglobin $(\mathrm{Hb})$ in red blood cells (WHO, 2016)

According to the World Health Organization (WHO) (2016), the definition of anemia is a state of hemoglobin $(\mathrm{Hb})$ level $<11 \mathrm{~g} / \mathrm{dl}$ and is said to be severe anemia if the $\mathrm{Hb}$ level is $<7 \mathrm{~g} / \mathrm{dl}$. Iron deficiency anemia is defined as an $\mathrm{Hb}$ level $<11 \mathrm{~g} / \mathrm{dl}$ and there is at least one criterion of iron deficiency. Under no circumstances, iron requirements can usually be met from a healthy and balanced diet. But in a state of pregnancy, iron supply from food is still insufficient so that a supplement is needed in the form of iron tablets.

According to Riskesdas (2013), in Indonesia pregnant women who do not take iron tablets for reasons do not know or forget to drink by $19.3 \%$. In addition to the provision of iron tablets, the knowledge of pregnant women on anemia is very important as in the study of Rajeev Kumar, et al (2014) which states that the knowledge of pregnant women about the causes of anemia, signs and symptoms of anemia and foods that can prevent anemia are obtained less. Knowledge of pregnant women about anemia is significantly related to the education of pregnant women. The results of other studies stated that $85 \%$ of pregnant women did not know the Hb levels in their blood. Therefore, pregnant women can experience severe anemia directly due to lack of information and knowledge of maternal health status and efforts to prevent it (Fredanna, 2014).

One way to prevent anemia in pregnant women is to give iron tablets. However, the administration of iron tablets on a regular basis will be in vain if the pregnant woman does not consistently take the iron tablets during pregnancy. Compliance with iron tablets is measured by the accuracy of the number of tablets consumed, the accuracy of how to consume iron tablets and the frequency of consumption per day. Maternal compliance in consuming iron tablets is influenced by several factors, one of which is maternal knowledge of iron tablets and prevention of anemia (Budiarni, 2012).

\section{MATERIALS AND METHODS}

The research's method conducted using pre-experimental one group pre-test and post-test design. The subjects were first trimester-pregnant women who performed antenatal care at PMB Putu Mastiningsih, for totally 30 patients. They were assessed about their level of knowledge using anemia-related questions, just before they received the health education. At the end of the session, their level of knowledge was re-measured using a questionnaire. Those data then analyzed by using a univariate and bivariate analysis to determine the effect of health education on anemia in first trimester-pregnant women on the level of knowledge about anemia. The study was conducted within May-July 2018. 


\section{RESULTS}

\section{Univariate Analysis}

\section{a. Level of Knowledge Before Given Health education about anemia}

Table 4.1 Distribution of Respondents by Level of Knowledge Before Given Health education about anemia

\begin{tabular}{ccc}
\hline Category & Frequency $(\mathbf{F})$ & Percentage (\%) \\
\hline Less & 9 & 30,0 \\
Enough & 17 & 56,7 \\
Good & 4 & 13,3 \\
\hline Total & 30 & 100 \\
\hline
\end{tabular}

From table 4.1 shows that respondents who have a good level of knowledge as many as 4 people $(13.3 \%)$, a sufficient level of knowledge as many as 17 people $(56.7 \%)$ and who have a level of knowledge of as many as 9 people $(30 \%)$.

\section{b. Level of Knowledge After Given Health Education about Anemia}

Tabel 4.2 Distribution of Respondents by Level of knowledge after provided the counseling about health education of anemia

\begin{tabular}{ccc}
\hline Category & Frequency $(\mathbf{F})$ & Percentage $(\%)$ \\
\hline Less & 0 & 0 \\
Enough & 8 & 26,7 \\
Good & 22 & 73,3 \\
\hline Total & 30 & 100 \\
\hline
\end{tabular}

From table 4.1 shows that respondents who have a good level of knowledge as many as 22 people $(73.3 \%)$, the level of knowledge is enough as many as 8 people $(26,7 \%)$ and no one has a lack of knowledge.

\section{Bivariate Analysis}

\section{Influence of health education Levels Before and After Given Health Education about Anemia}

Tabel 4.3 The influence of the level of knowledge of respondents before and after being given health education about anemia

\begin{tabular}{ccccc}
\hline Kategori & Mean rank & Sum of Rank & P value & Z \\
\hline Knowledge before and after research & 11,0 & 231,0 & 0,001 & $-4,208$ \\
\hline
\end{tabular}

In table 4.3 , it obtained a positive rating of 11.0 with a value of $p=0.001$, which means less than the value of $\alpha=0.05$. This shows that the results of statistical tests have the effect of health education about anemia to level of knowledge of first-trimester pregnant women about anemia in PMB Putu Mastiningsih.

\section{DISCUSSION}

Based on the results of the study in tables 4.1 and 4.2 there were differences in knowledge of pregnant women about anemia before and after being given health education which was seen from the lowest and highest values before and after being given health education. In table 4.1 before being given health education, respondents who have a good level of knowledge are 4 people (13.3\%), 
sufficient level of knowledge is 17 people (56.7\%) and those who have a level of lack of knowledge are 9 people (30\%) while in table 4.2 after being given health education of respondents who have a good level of knowledge as many as 22 people (73.3\%), sufficient level of knowledge is 8 people (26, $7 \%$ ) and no one has a lack of knowledge. Health education is the application of education in the health sector where the activities aim to increase knowledge, attitudes and practices in personal life and society as an effort to improve health (Notoadmojo, 2011).

In line with the goals of health education, in this study based on the results of research in table 4.3 shows a change in the level of maternal knowledge before and after being given health education with $\mathrm{p}$ value $<0.05$ which means $\mathrm{Ha}$ is accepted ie there is the influence of health education about anemia on the level of knowledge of mothers pregnant at PMB Putu Mastiningsih. The results of this study indicate that health education can increase the knowledge of pregnant women about anemia. Knowledge is the result of sensing a person towards a particular object through vision, smell, taste and touch. Knowledge is a very important domain for the formation of maternal knowledge about anemia so prevention measures can be taken (Notoadmojo, 2011). Health education conducted in this study received a good response from respondents. This can be seen from the activity of respondents in expressing questions about pregnancy and anemia in the question and answer session. This activity provides new insights and knowledge for respondents so they can understand and maintain the health of their pregnancies from anemia. Anemia that often occurs in pregnant women is iron deficiency anemia namely lack of iron due to the process of hemodilution. Iron functions essential for fetal growth include involvement in energy metabolism, gene regulation, cell growth and differentiation, oxygen binding and transportation, muscle oxygen use and storage, enzyme reactions (Prakash, 2015).

The results of this study are in line with Sianipar's (2016) study with one group pre-test pretest and post-test research methods on 30 respondents whose results stated that there was an effect of health education ( $p$ value $<0.05$ ) on the level of knowledge of pregnant women in Bukit Hindu Puskesmas Palangka Raya. Another study which stated the same results was a study by Makmun (2016) through a quasy experiment study with pretest and post-test non-equivalent control group design on 58 respondents who stated that there was an effect of providing health education on knowledge, attitudes and behavior of consuming Fe tablets in pregnant women anemia.

\section{CONCLUSION}

Based on the results of the study it was concluded that there was a positive effect of health education of anemia to the knowledge of first-trimester pregnant women at PMB Putu Mastiningsih with $\mathrm{p}$-value $<0.05$. This study may be a potential benefit for improving the implementation of health education in midwifery practice to increase pregnant women's awareness in preventing anemia.

\section{REFERENCE}

Badan Pusat Statistik. (2015). Profil Penduduk Indonesia Hasil SUPAS. Jakarta.

Budiarni, W. (2012). hubungan pengetahuan, sikap dan motivasi dengan kepatuhan konsumsi tablet besi folat pada ibu hamil. Universitas Diponegoro.

Dinas Kesehatan Provinsi Bali. (2015). Profil Kesehatan Bali Tahun 2014.

Fredanna, A., D., Cormack, M., \& Drolet Judy, C. (2012). Assessment of Anemia Knowledge, Attitudes and Behaviors Among Pregnant Women in Sierra Leone. Departemnet of Health Sciences Costal Carolina University. 44.

Kementerian Kesehatan RI. (2013). Riset Kesehatan Dasar (Riskesdas). Badan Penelitian dan Pengembangan Kesehatan Kementerian Kesehatan RI. Jakarta.

Makmun, I., \& Raden, A. (2016). Pengaruh Pemberian Pendidikan Kesehatan terhadap Pengetahuan, Sikap dan Perilaku Mengkonsumsi Tablet FE pada Ibu Hamil dengan Anemia. Jurnal Ilmiah Umum dan Kesehatan. 2016;1(2);126-134. 
Notoatmodjo, \& Soekidjo. (2011). Kesehatan Masyarakat Ilmu dan Seni. Jakarta: Rineka Cipta.

Prakash, S., \& Yadav, K. (2015). Maternal Anemia in Pregnancy: An Overview. International Journal of Pharmacy \& Pharmaceutical Research;4(3);164-179.

Rajeev Kumar Yadav, M., K., Swamy, \& Banjade, B. (2014). Knowledge and Practice of Anemia among pregnant women attending antenatal clinic in Dr. Prabhakar Kore hospital, Karnataka-A Cross sectional.

Sianipar, S., S., Aziz, Z., A., \& Prilia, E. (2016). Pengaruh Pendidikan Kesehatan tentang Anemia Pada Kehamilan terhadap Pengetahuan Ibu Hamil di UPT Puskesmas Bukit Hindu Palangka Raya. Dinamika Kesehatan;7(1);266-268.

World Health Organization. (2016). WHO recommendations on antenatal care for a positive pregnancy experience. Luxembourg: WHO. 